\title{
The Impact of Charcoal Production on the forest of Sub-Saharan Africa: A theoretical Investigation
}

\author{
Patrick K. Ansah ${ }^{1}$ \\ ${ }^{1}$ Regent University College of Science and Technology Accra, Ghana \\ Correspondence: Patrick K. Ansah, Lecturer in Economics, Regent University College of Science and Technology \\ Accra, P.O. Box DS 1636, Dansoman, Accra, Ghana. E-mail: paakojogha76@gmail.com; \\ paakojogha@yahoo.com
}

Received: August 17, 2021

Accepted: January 15, $2022 \quad$ Online Published: January 28, 2022

doi:10.5539/jsd.v15n2p16

URL: https://doi.org/10.5539/jsd.v15n2p16

\begin{abstract}
This paper examines the sustainability of charcoal production that maximizes social welfare based on optimal control techniques visa-vis the activities of profit maximizing charcoal producing firms in South Sahara Africa. I set up a theoretical model involving the socially optimal charcoal production that will maximize the socially optimal discounted sum of net benefit of Charcoal production for both the private profit maximization firm and that which will yield sustainability. After solving for the optimal choices for both functions it reveals that there is indeed divergence between these two entities simply because environmental degradation and deforestation (externalities) associated with charcoal production are not internalized into the production function of the profit maximizing charcoal producing firms. These externalities would lead to unsustainability of the forest environment and subsequently deforestation. Fiscal policy measures and public ownerships are recommended to deal with externalities that are inherent in charcoal production so as to improve sustainability while ensuring charcoal continues to provide livelihood benefits for the numerous people that live in the charcoal producing belt.
\end{abstract}

Keywords: sustainability, charcoal production, optimal control, externalities

\section{Introduction}

Charcoal is a prime source of energy in most African countries, and is a driving force in their economies. Worldwide charcoal production has increased, rising by an annual 3.7\% from 1990 to reach 44 million tons in 2000(FAO 2008). Surprisingly, policy makers pay little attention to the ways in which charcoal is produced and sold and whether wood used for charcoal burning is harvested in a sustainable fashion or not. The environment, which is considered generally as a free gift of nature, has undergone serious transformation in the hands of man. This to a large extent is due to man's efforts to satisfy himself which leads to environmental degradation such as deforestation. The exploitation of the environment through farming, fishing, mining, lumbering, fuelwood, as well as charcoal production has socio-economic, environmental and policy implications to countries, especially when they are not well regulated (Mugo, F and Ong, C, 2006). These activities exert both short and long term impacts on the environment (Peter, et al., 2009). Land degradation is one single mark of man's existence on earth since time immemorial, from simple tilling of the land with hoes and cutlasses, and hunting with bow and arrows to the present day sophisticated methods of exploiting the environment through ploughing, gaming, manufacturing, fishing, lumbering, and mining). Based on this, the human population has transformed the environment at different levels and at different places depending on available technology and policies (Kammen and Lew, 2005; UNDP, 2014b). One area that has seen a dramatic transformation across the world as a result of human activities is the world forest, from its natural state to transitional zones and in many cases totally transformed. Areas which were in the past seriously forested have been converted into dry or desert lands and desert conditions keep on crippling into savannah areas and other vegetation zones. It is estimated that about $25 \%$ of the world's forest harvested for fuel is converted into charcoal for domestic and industrial purposes (FAO, 2010). The role of charcoal as a reliable and vital source of energy for millions of people around the globe and one of the most commercialized resources in sub-Saharan Africa cannot be sustained without coherent policies. Almost all charcoal production, transportation, and distribution remain informal and unregulated - leading to inefficient and risky production methods because policies to effectively govern the sector are lacking in many countries. Authorities in most countries around the world tend to view charcoal production and use as an environmental and health problem. 
However, if managed properly charcoal can provide a low-cost and locally available energy source that has the potential to become sustainable and contribute significantly to poverty alleviation.

\section{Trends in Charcoal Production in the Study Area}

International demand for charcoal is fueled mainly by the Gulf States, and in Somalia alone generates an estimated US\$360 million to US\$384 million of income per year Charcoal from Somalia is exported to Yemen, Saudi Arabia, Kuwait, Egypt and the United Arab Emirates via dhows and small freighters. Militant groups typically control borders and export points along the supply chain for locally produced charcoal, and considerable illegal profit is made from unregulated taxes (Brown, 2014).
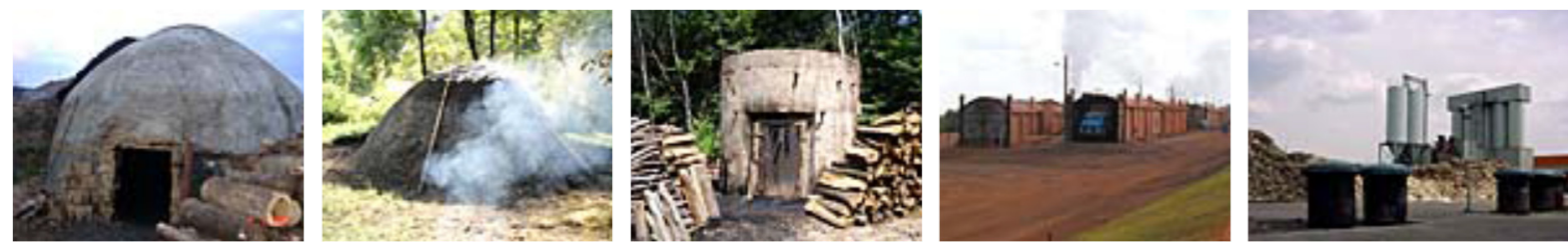

Source: FAO (2008). Below are graphs representing the export value and export quantity of Charcoal in Africa
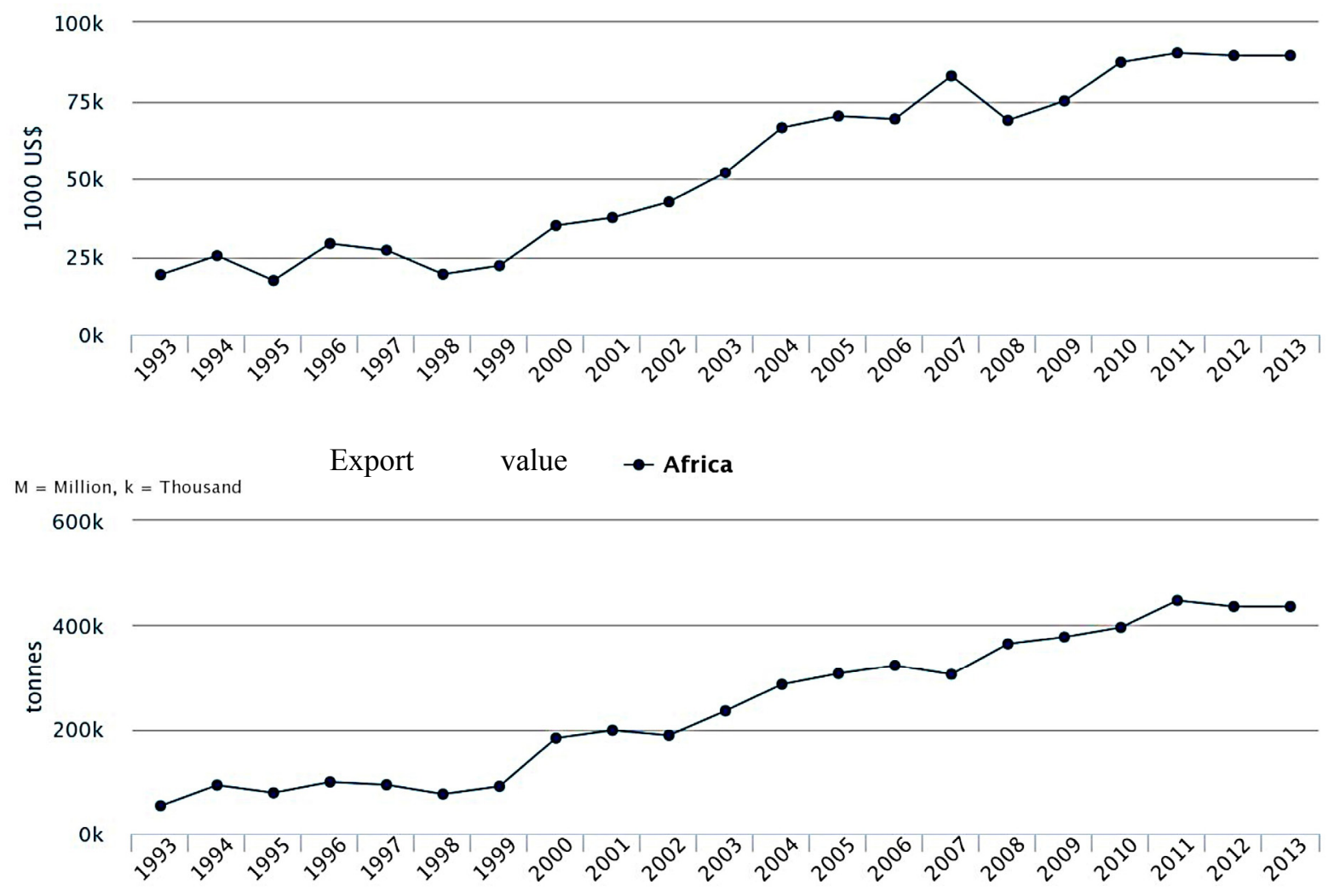

$M=$ Million, $k=$ Thousand

$$
\text { Export quantity } \rightarrow \text { Africa }
$$

Figure 1. Export value and quantity of charcoal in Africa from 1993-2013

Source: (FAOSTAT, 2014)

WSP (2001) estimated the charcoal output of north--east Somalia in 1996 at 120,000 to 144,000 tons, 80 percent of which was exported. Producing this volume required cutting about 2.1 million Acacia nilotica trees (favored for charcoal production and export to the Gulf States because of its slow burn rate and scented wood). At an average density of 60 trees per hectare, this translates into a deforestation rate of 35,000 hectares of land per year. Reports indicate that the export demand for charcoal has surpassed supply and the harvest of trees has spread into neighbouring countries such as Ethiopia (IUCN, 1997). With export quantity and value of charcoal increasing steadily since 1993 (Figur1), there is good reason to believe that the charcoal sector will continue to fund 
international terrorism. There is a commonly held theory that charcoal serves as a 'transition' fuel, i.e. as households and countries grow economically, people's energy preference transition also go up from 'inferior' biomass fuels ladder through charcoal to modern alternatives such as LPG, kerosene and electricity. However, charcoal is not primarily used by low - income households; it is consumed across a wide range of income categories without a lot of variation in per capita consumption (Mwapamba, 2007). In Ghana a survey of 8,686 households revealed that both charcoal and gas use increased with income, but a greater number of the richer households used charcoal rather than gas. Figure 2 below shows the relationship between household income and the number of households using wood, charcoal and liquefied petroleum gas in Ghana.

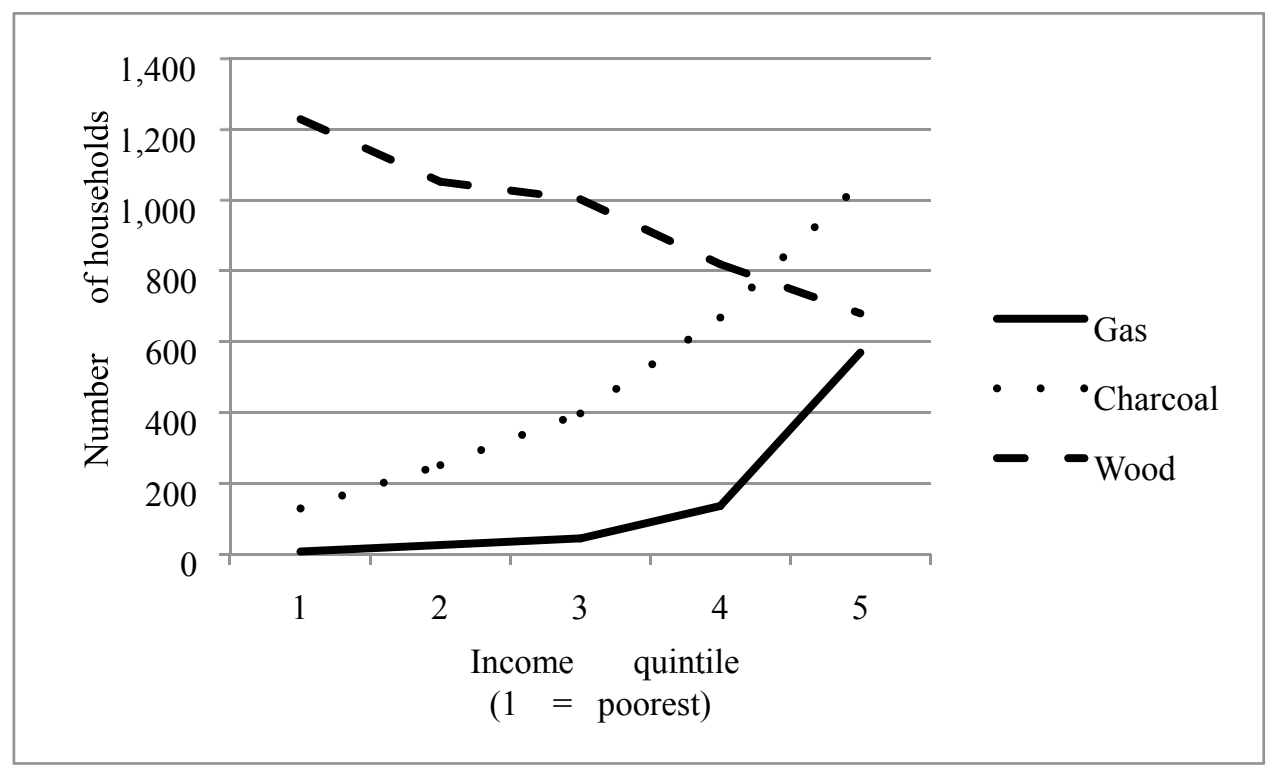

Figure 2. Wood, charcoal and gas usage in Ghana

Source: Adapted from Adam, et al. (2013)

The IEA (2010) states that the number of people in sub-Saharan Africa relying on traditional use of biomass may increase to 918 million by 2030. While at present, charcoal and firewood are used in almost equal proportions, charcoal demand is expected to grow at a higher rate (56 percent by 2030) than fuelwood demand (GEF, 2013). Therefore, the charcoal sector may provide the main source of livelihood in rural and urban areas for ca. 12 million people by 2030, up from the current figure of around 7 million (Mwampamba et al. 2013a). ICRAF (2002) estimated that charcoal creates 200 to 350 job--days per Terajoule consumed, compared to 80-110 for electricity, 10-20 for LPG and 10 for kerosene. Thus, the charcoal sector has an important role in job creation, and with growing demand, opportunities in the sector are increasing. Large numbers of people are attracted to the commercial production and sale of charcoal as there is stable demand, ease of access to forest resources and low initial investment costs (Arnold, et al. 2006). Charcoal provides alternative income generation in rural areas and employment opportunities through small retail businesses in urban areas (Zulu, LC. 2010). The rural poor benefit through their role in charcoal production or as small transporters, wholesalers or contract labourers involved in loading, repairing or driving trucks (Minten, et al. 2013). Farmers who make use of trees felled during land clearing enhance their social and economic security through charcoal production (Zulu and Richardson 2013), supplementing farm income and enabling them to purchase grains and other household commodities when foodsupplies run low during the off--season. The urban poor benefit from the charcoal sector through employment as charcoal transporters, retailers or producers/retailers of stoves (Minten, et al. 2013). At country level, charcoal has been estimated to contribute annually: for instance, US\$650 million to Tanzania's economy; 5.8 times the combined value of coffee and tea production (World Bank 2010), US\$450 million in Kenya; comparable to the country's tea industry (ESDA, 2005). However, a recent survey suggests that the sector is now worth US\$1.6 billion (KFS,2013), US\$77million in Rwanda (vanderPlas,2008). Charcoal provides urban households with a convenient and reliable source of energy for cooking, heating and small-scale industrial activities at relatively stable prices while ensuring energy security (Zulu and Richardson, 2013); Charcoal is also considered a 'cleaner' option than firewood as it produces less smoke (Liyama, et al.,2015. It is widely available in the form that people 
can readily use and is far more affordable and accessible than LPG, kerosene or electricity (Bailis, et al. 2005, Brew and Kemausour, 2009). In addition, the quantity of charcoal purchased can be adjusted to a household's available cash. In Africa, much of charcoal production is unsustainable (Zulu and Richardson, 2013). Recently, Bailis et al, (2005) and Liyama, et al. (2014a) assessed that between 27 and 34 percent of African wood fuel was harvested unsustainable in 2009, while in hotspots in Eastern and Southern Africa most of the demand was unsustainable. Rapid urbanization and population growth in Sub- Saharan Africa means business as usual in charcoal production will lead to serious land use changes, especially, dryland, forest woodland degradation. The biomass used in charcoal production in Sub Saharan Africa is sourced predominantly from unreserved natural forests or woodlands on village land or from farmland that is being cleared for agriculture and may also follow forest clearing (Hofsted, et al., 2009), except a few outlies such as in Rwanda where most charcoal is derived from trees that have been planted on private tree plantations on median less than 2 hectors (World Bank, 2012, Drigo, et al., 2013.). In Kenya for example, drylands are reported to provide over 75 percent of the hard wood used to make charcoal. According to Chidumayo and Gumbo, (2014), Tabuti, et al., (2003) and Kissinger, et al., (2012) harvested wood is generally converted to charcoal in rudimentary earth kilns with a conversion rate ranging from 8 to 20 percent. While the main driver of deforestation is Agriculture, charcoal production to can lead to severe deforestation at local scales and near production sites. Estimates of annual deforestation range from $5.4 \mathrm{~km}^{2}$ in Oceania to $29,760 \mathrm{~km}^{2}$ in Africa, which accounts for nearly 80 percent of global charcoal- base deforestation. Through selective logging, charcoal production more commonly contributes to forest degradation than cutting. Below are figures that illustrate the deforestation nature as a result of Charcoal production.
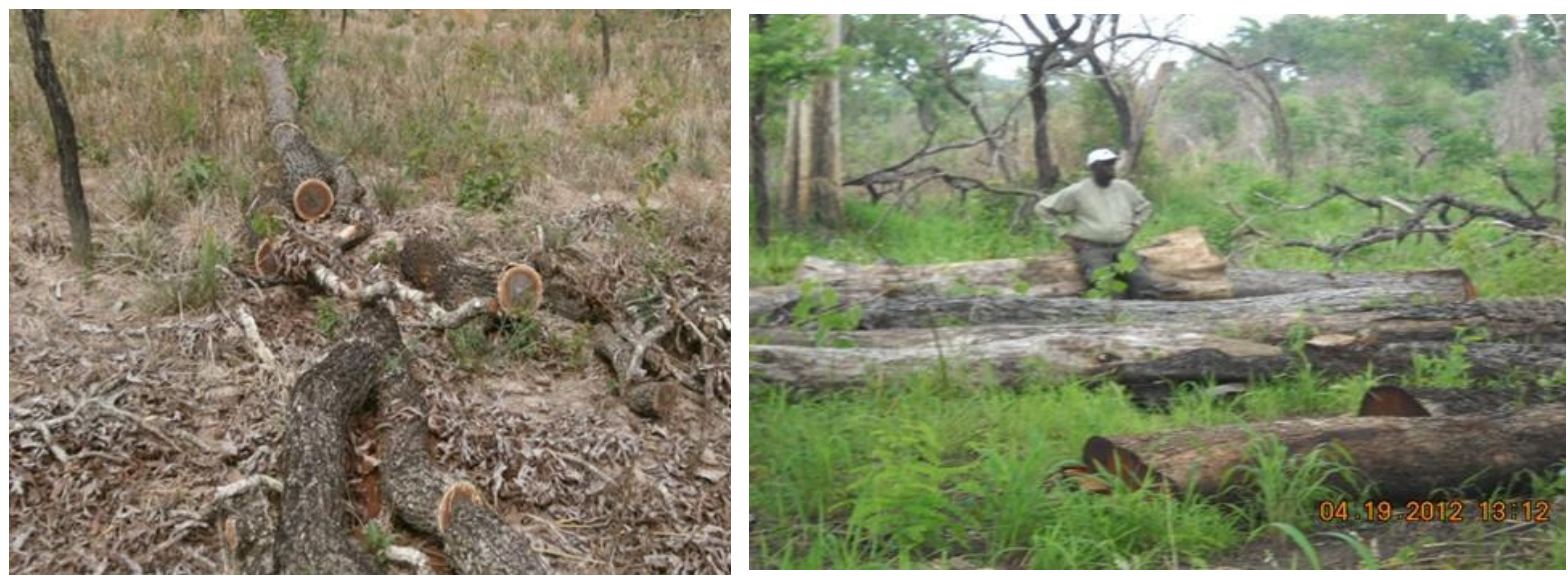

Figure 3. Indiscriminate felling of trees for charcoal burning

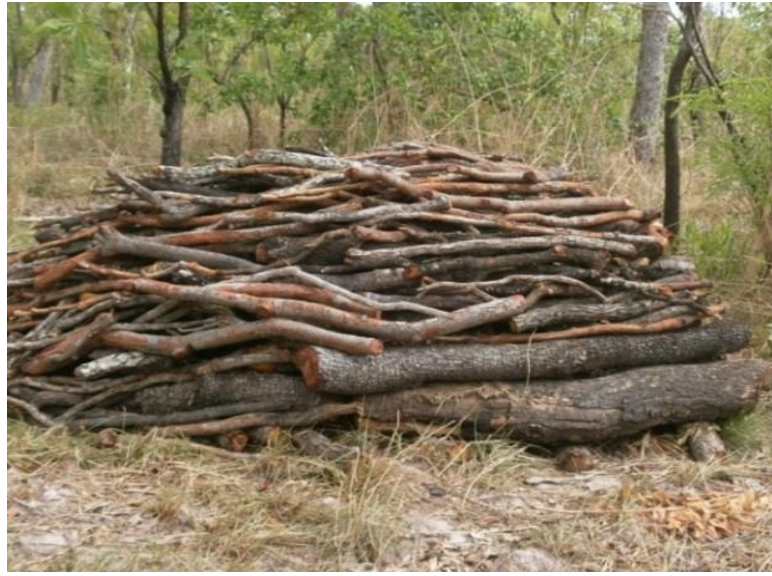

Figure 4. A pole of wood ready to be covered for burning

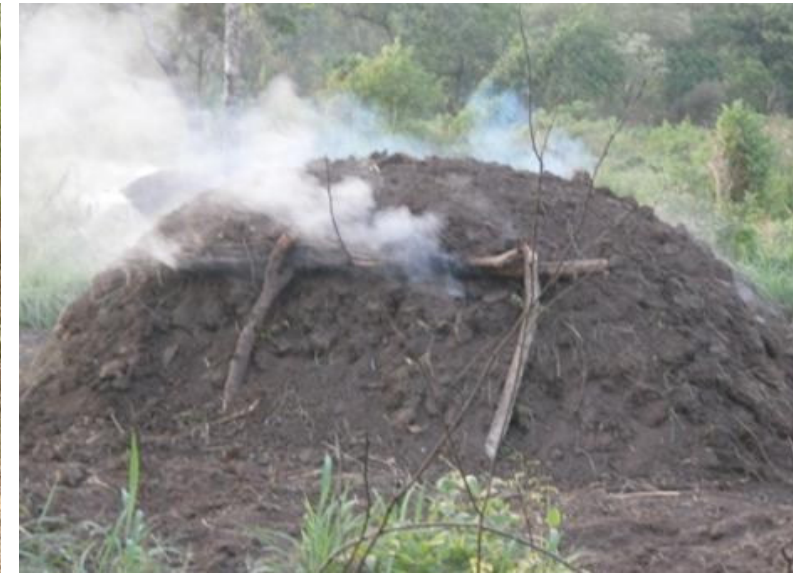

Figure 5. Charcoal burning by the traditional earth mound method

Source: FSD Ghana (2015) 

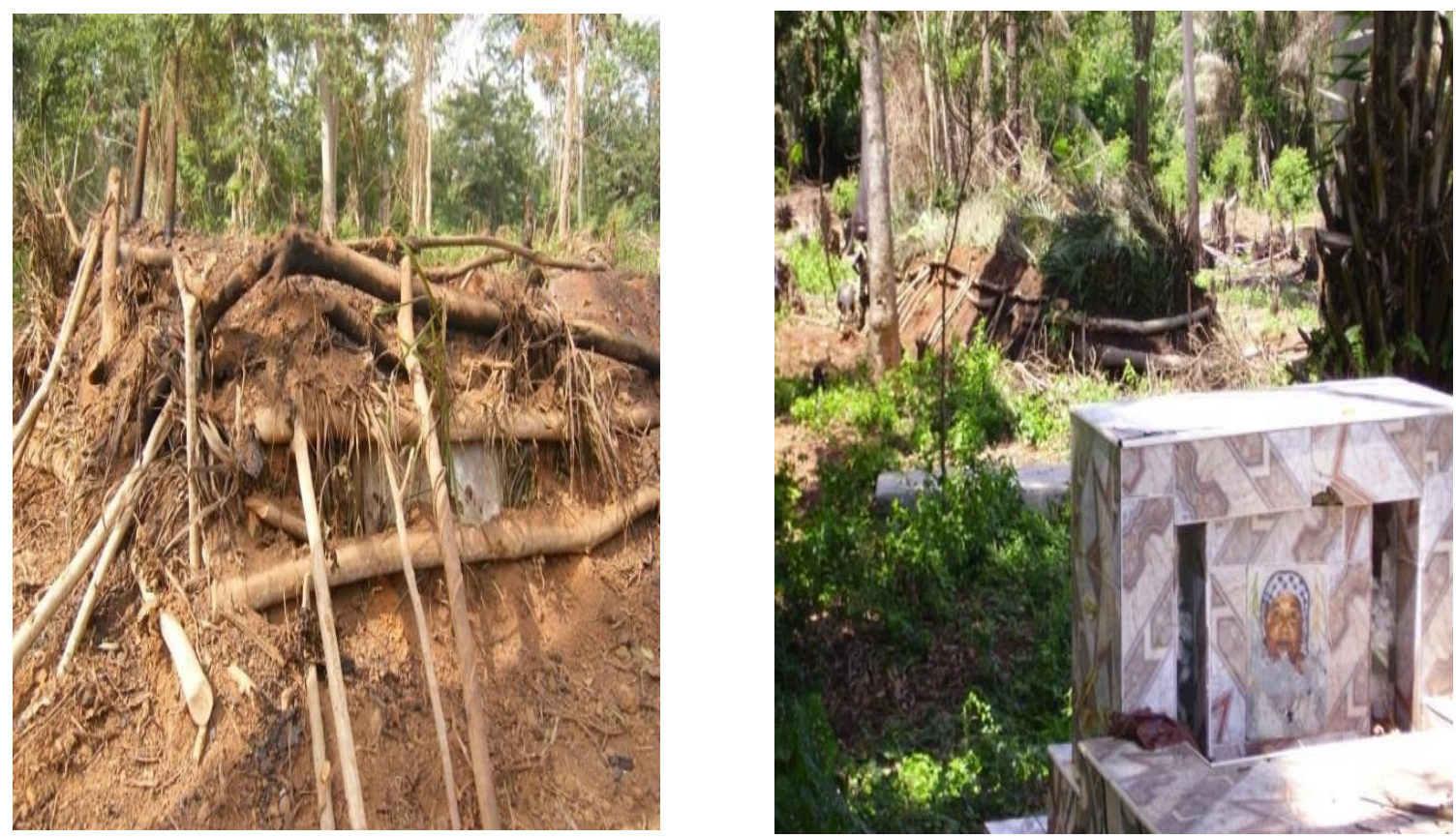

Figure 6. Woodfuel harvesting is characterized by widespread environmental abuses as depicted below by empirical evidence of charcoal burning at a public cemetery

Source: FSD Ghana (2015)

In addition to biomass related carbon loss, localized deforestation due to extraction for charcoal around major cities in Sub Saharan Africa has caused associated environmental degradation and reduction of ecosystems services resulting in lower agricultural productivity. Degraded forest attributed to charcoal production has an impact on forest goods such as fruits, bush meat, medicines erosion control, water quality biodiversity. (Zulu, LC. 2010, Naughton, et al, 2007). Anold and Person, (2003) and Kammen and Lew, (2005) and Luoga, et al., (2000) are of the view that environmental cost of degradation associated with charcoal production are difficult to quantify and are not reflected in the product price. This contributes to resource depletion and threatens sustainability. Globally, Africa is the largest emitter of greenhouse gases from charcoal production, accounting for about two-thirds of total world emissions. In Africa it is estimated that wood fuel (including firewood and charcoal) constitutes nearly 90 percent of wood consumed for energy purposes (UNEP 2014). In sub-Saharan Africa, biomass is used by more than 80percent of urban households as their main source of cooking energy (GEF, 2013). FAO (FAOSTAT, 2014) estimates official charcoal production for Africa to be 30.6 million tons in 2012 (figure 1) and this is worth between US\$9.2 billion and US\$24.5 billion annually (UNEP, 2014). Fueled by rapid population growth, urbanization and the increasing cost of alternative fuels, the demand for charcoal is expected to double in Africa by 2030 (Arnold, et al. 2006). At the current level of kiln efficiency, the annual demand for charcoal translated into the amount of forest required area will rise from 1.5 million hectares today to nearly 4.5 million hectares of forestry land in 2050 (Liyama, et al., 2014a). Below is a figure showing charcoal production in Africa 


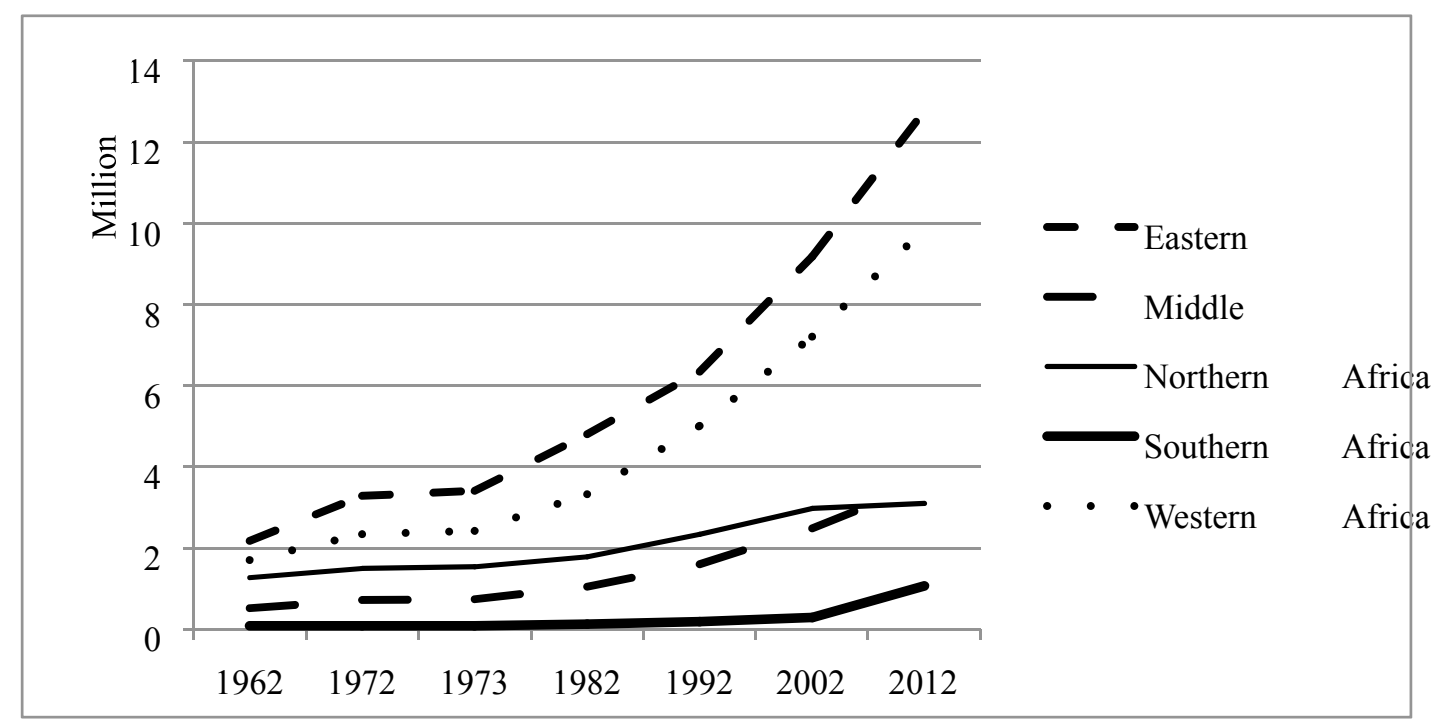

Figure 7. Charcoal Production in Africa

Source: FAOSTAT (2014)

\section{The model}

This section presents the model and analytical results of the paper. Let $Y$ be the total land available for forest and charcoal production in Sub Sahara Africa, measured in hectares. In Sub Sahara Africa most charcoal producing lands were originally covered by virgin rain forest (forest wood). Let us denote the forest stock (wood) by $F$ also measured in hectares and assume for ease of exposition that the initial values of $Y$ and $F$ are equal implying that the total land area were initially covered by forest (wood). In order to produce charcoal, at time $t$, the firm requires labour $(L(t))$, capital $(K(t))$, purchase inputs for charcoal production $(Z(t))$, land $(N(t))$, forest $\operatorname{wood}(\mathrm{F}(\mathrm{t}))$ and deforestation $(\mathrm{D}(\mathrm{t}))$.

The charcoal production function takes the following form:

$$
X(t)=f[(L(t), K(t), Z(t), N(t), \mathrm{F}(\mathrm{t}), D(t)],
$$

Where $X(t)$ is charcoal yield (output) at time $t$, and $Z(t)$ is a vector of purchase inputs for charcoal production. Labour and capital act as complement. The production function is assumed to exhibit diminishing but positive marginal returns in each of its six arguments.

The isocost of the charcoal producing firm is given by equation 2 . Where $C(t)$ is the total amount at time $t$, to be spent on all inputs into charcoal production, $w$ is the agricultural wage rate, $r$ is the rental cost of capital, $x$ is the price per hectare of forest wood and $q$ is the vector of prices for purchase inputs. Factor markets are assumed to be competitive so factor prices are taken as given (they are exogenous to the model) and each factor is rewarded with its marginal contribution to total output. Note that deforestation and degradation are outside the cost equation. The reason for omitting them is that their costs are external to the firm once the labour and capital needed to feel the trees and produce the charcoal have been accounted for. The implication is that from the view point of the firms, deforestation as well as land degradation is the cheapest among all the inputs into production of charcoal. This is the Genesis of the unsustainability of forest and hence charcoal production problem in Sub Sahara Africa.

$$
\mathrm{C}(\mathrm{t})=\mathrm{wL}(\mathrm{t})+\mathrm{rK}(\mathrm{t})+x \mathrm{~F}(\mathrm{t})+\sum \mathrm{qi} \text { zi }
$$

$\mathrm{i}=1$ 
Thus Sub Sahara forest wood has been classified into the class of exhaustible resources (Ehui, et al., 1989). This is reasonable when the benefits of the forest is viewed broadly to include non-commercial use such as carbon store, biodiversity, option value, climate regulation and recreational amenities in addition to timber, forest wood and agricultural use The forest stock must therefore satisfy the following dynamic equation:

$$
\frac{\mathrm{dF}(\mathrm{t})}{\mathrm{dt}}=-\mathrm{D}(\mathrm{t})
$$

From equation (3), it implies that the forest wood stock at any point in time decreases by the total amount of deforestation and land degradation measured in hectares during the same time period under consideration. This is a typical dynamic equation to characterize the stock dynamics of an exhaustible resource.

\subsection{The Charcoal Firms Production Activities}

The charcoal firm's problem is to choose the amount of each input to maximize the discounted profit. Equation 4 spells out the firm's problem more formally.

n

$$
\operatorname{Max} Л=\int\left[p f[\mathrm{~L}(\mathrm{t}), \mathrm{K}(\mathrm{t}), \mathrm{Z}(\mathrm{t}), \mathrm{D}(\mathrm{t}), \mathrm{F}(\mathrm{t})]-\left[\mathrm{wL}(\mathrm{t})+\mathrm{rK}(\mathrm{t})+\varkappa \mathrm{F}(\mathrm{t})+\sum \mathrm{qiZi}\right]\right] \mathrm{e}^{-} \theta \mathrm{t} \mathrm{dt}
$$

This leads to maximizing profit in each period. Thus, stated differently in its static equivalent form the above dynamic maximization problem can be stated as:

$$
\operatorname{Max} Л=p f[\mathrm{~L}(\mathrm{t}), \mathrm{K}(\mathrm{t}), \mathrm{Z}(\mathrm{t}), \mathrm{D}(\mathrm{t}), \mathrm{F}(\mathrm{t})]-\left[\mathrm{wL}(\mathrm{t})+\mathrm{rK}(\mathrm{t})+x \mathrm{~F}(\mathrm{t})+\sum \mathrm{qiZi}\right]
$$

The appropriate first order conditions are given by equations 6-10. These conditions imply that the firms would employ each input to the point where the value of the marginal product of each input is equal to its price. Since deforestation is a free input in charcoal production once the labour and capital costs are taking care of, the firms set the value of marginal product of deforestation and land degradation to zero. This is a clear indication that the chosen path of these charcoal producing firms is socially sub-optimal. This calls for public policy intervention to internalize the cost of the externalities. This is the core of the problem of deforestation and land degradation in the South Sahara Africa. Firms have sort to increase charcoal production yield by using more of the less expensive input, deforestation and land degradation.

$$
\begin{gathered}
\frac{\partial Л}{\partial \mathrm{L}}=0 \rightarrow \mathrm{p} \frac{\partial \mathrm{f}(\cdot)}{\partial \mathrm{L}}-w=0 \rightarrow \mathrm{p} \frac{\partial \mathrm{f}(\cdot)}{\partial \mathrm{L}}=w \\
\frac{\partial Л}{\partial \mathrm{K}}=0 \rightarrow \mathrm{p} \frac{\partial \mathrm{f}(\cdot)}{\partial \mathrm{K}}-r=0 \rightarrow \mathrm{p} \frac{\partial \mathrm{f}(\cdot)}{\partial \mathrm{K}}=r \\
\frac{\partial Л}{\partial \mathrm{F}}=0 \rightarrow \mathrm{p} \frac{\partial \mathrm{f}(\cdot)}{\partial \mathrm{F}}-\mathcal{X}=0 \rightarrow \mathrm{p} \frac{\partial \mathrm{f}(\cdot)}{\partial \mathrm{F}}=\mathcal{X} \\
\frac{\partial Л}{\partial \mathrm{Z} \mathrm{i}}=0 \rightarrow \mathrm{p} \frac{\partial \mathrm{f}(\cdot)}{\partial \mathrm{Zi}}-\mathrm{qi}=0 \rightarrow \mathrm{p} \frac{\partial \mathrm{f}(\cdot)}{\partial \mathrm{Zi}}=\mathrm{qi} \\
\frac{\partial \pi}{\partial \mathrm{D}}=0 \rightarrow \mathrm{p} \frac{\partial \mathrm{f}(\cdot)}{\partial \mathrm{D}}=0
\end{gathered}
$$

Equation (10) confirms the assertion that Authorities in countries around the world tend to view charcoal production and use in South Sahara Africa as an environmental and health problem. (Neufedt, et al. 2015)

However, if managed properly charcoal can provide a low-cost and locally available energy source that has the potential to become sustainable and contribute significantly to poverty alleviation.

This brings to the fore the need to choose the maximization path of charcoal production that guarantees the sustainable use of the forest. Next, let us derive the socially optimal condition for charcoal production in South Sahara Africa based on sustainability. 


\subsection{Charcoal Sustainability}

Now consider a benevolent social planner who wishes to maximize the discounted value of net revenues from charcoal subject to the dynamics of the forest stock. Thus, the planner maximizes equation (4) subject to equation (3). The current value Hamiltonian for the dynamic optimization problem facing the planner is:

$\mathrm{n}$

$$
\mathrm{H}=\mathrm{p} f[\mathrm{~L}(\mathrm{t}), \mathrm{K}(\mathrm{t}), \mathrm{Z}(\mathrm{t}), \mathrm{F}(\mathrm{t}), \mathrm{D}(\mathrm{t})]-\left[\mathrm{wL}(\mathrm{t})+\mathrm{rK}(\mathrm{t})+x \mathrm{~F}(\mathrm{t})+\sum \mathrm{i} \mathrm{iZi}\right]-\lambda \mathrm{D}(\mathrm{t})-
$$

The application of Pontryagin's maximum principles yields the following necessary conditions that must be satisfied along an optimal time path.

$$
\begin{aligned}
& \frac{\partial \pi}{\partial \mathrm{L}}=0 \rightarrow \mathrm{p} \frac{\partial \mathrm{f}(\cdot)}{\partial \mathrm{L}}-w=0 \rightarrow \mathrm{p} \frac{\partial \mathrm{f}(\cdot)}{\partial \mathrm{L}}=w \\
& \frac{\partial \pi}{\partial \mathrm{K}}=0 \rightarrow \mathrm{p} \frac{\partial \mathrm{f}(\cdot)}{\partial \mathrm{K}}-r=0 \rightarrow \mathrm{p} \frac{\partial \mathrm{f}(\cdot)}{\partial \mathrm{K}}=r \\
& \frac{\partial \pi}{\partial \mathrm{F}}=0 \rightarrow \mathrm{p} \frac{\partial \mathrm{f}(\cdot)}{\partial \mathrm{F}}-\mathcal{X}=0 \rightarrow \mathrm{p} \frac{\partial \mathrm{f}(\cdot)}{\partial \mathrm{F}}=\mathcal{X} \\
& \frac{\partial \pi}{\partial \mathrm{Zi}}=0 \rightarrow \mathrm{p} \frac{\partial \mathrm{f}(\cdot)}{\partial \mathrm{Zi}}-\mathrm{qi}=0 \rightarrow \mathrm{p} \frac{\partial \mathrm{f}(\cdot)}{\partial \mathrm{Zi}}=\mathrm{qi} \\
& \frac{\partial \pi}{\partial \mathrm{D}}=0 \rightarrow \mathrm{p} \frac{\partial \mathrm{f}(\cdot)}{\partial \mathrm{D}}-\lambda=0 \rightarrow \mathrm{p} \frac{\partial \mathrm{f}(\cdot)}{\partial \mathrm{D}}=\lambda \\
& \frac{\lambda}{\lambda}=\theta
\end{aligned}
$$

As can be seen from the first order conditions of the sustainability's problem, equations 13-16 are exactly the same as equations 6-10 in the firm's problem. Sustainability employs each input up to the point where the value of marginal product of the input equal to its price. However the two entities, (the firm and sustainability) defer on their respective optimal choices for the amount of deforestation. Whilst the firm deforest until the value of marginal product of deforestation is zero (equation 10), the sustainable use of the forest will only deforest up to the point where the value of marginal product of deforestation is equal to the marginal social cost of $(\lambda)$ of deforestation (see equation 17). According to equation (18), the marginal social cost of deforestation grows at a rate equal to the social rate of discount. The implication of this is that impatient societies with high discount rate will deplete their forest wood stock faster and hence have their marginal social cost of deforestation increasing at an exponential rate. The marginal social cost of deforestation can be very large as the forest wood stock reduces. The social cost of deforestation also rest heavily on the weight the society puts on non-timber and agricultural uses of forest such as soil and water control, habitat support for biologically diverse system of animal and plant populations, recreational and aesthetic amenities, wilderness and existence/option values and climate control functions of the forest. In developed countries, it turns out that the non-commercial uses of the forest carries much weight; since the tropical forest is non-renewable within any reasonable biological and economic time scale. However, in the developing world, the demand for forest resources for commercial purposes is far higher than non-commercial uses such as recreational and aesthetic. This then suggest that poor regions (most of which are in the sub-Sahara Africa) will tend to have high rate of deforestation than their rich counterparts.

This means that the negative externality caused by sub-Sahara African deforestation can be very large resulting in a significant wedge between the socially optimal rate of deforestation and the optimal path taking by sustainable use of the forest. There is therefore the need for public policy intervention to internalize the externality caused by charcoal production. Relevant policy instruments to control deforestation are discussed in the next section of the paper.

\section{Policy Instruments}

Harvesting and production of wood fuels and other non-timber forest products (NTFP) should be done within sustainable limits on both reserve and off-reserve production areas. This could be achieved through the following actions:

Enacting the necessary legislation to support and ensure that forest, trees, wildlife and BTFPs on private and 
communal lands are managed according to the national forestry development objectives and resources owner's priorities.

Sub-Saharan Africa countries should develop Criteria and Indicators and a chain of custody to ensure that commercial production of wood fuels in all types of forests are sustainable.

They should develop a national regulatory framework for commercial exploitation of defined NTFPs at District levels. They should promote research and development programmes for commercially viable NTFPs.

Forestry serves multiple uses, therefore, in order to internalize the externalities in the forestry sector particularly in the Sub-Sahara Africa; government might use fiscal policy instruments, mainly, taxes and subsidies to internalize the externalities inherent in the forestry sector in order to ensure efficient and sustainable utilization of forest lands. Forest management can be improved by imposing a Pigouvian tax of $\lambda$ per forest wood cut for charcoal production. The imposition of the tax will raise the cost of deforestation and push the rate of deforestation towards the socially optimal rate. With the increase in deforestation cost, charcoal yield could be maintained by promoting the establishment of commercial and small holder wood fuel plantations both on and off forest reserves.

We could achieve Pareto improvement in forest land use by taxing charcoal producing inputs (labour and capital inputs such as chainsaw, axe etc.) that are complements to deforestation and use the proceeds to subsidize wood fuel plantations that served as substitutes to deforestation. Meanwhile, Subsidizing reforestation of degraded and marginal lands that is currently unsuitable for crop production will also be welfare improving. Though the biodiversity loss of clearing natural forests wood cannot be regained, reforestation can restore soil nutrient, help in carbon absorption and local climate regulations, among other things. Where non-timber values are large and their incidence is greatest in mature forest as is the case in the Sub-Saharan region in general, no felling may be justified. Government might seek such an outcome through fiscal incentives, but is more likely to do so through public ownership. Forest management problems are further compounded by international spill overs in forestry. Many of the non-timber values of forest resources are derived by people living in other countries. Many of the externalities associated with tropical deforestation cut across national borders (e.g. global climate change). This implies that there are limits to how much an individual national governments can do to promote efficient and sustainable forest land use. International concerted action is therefore a prerequisite of efficient and sustainable forest land use.

\section{Conclusion}

This paper investigated the conditions that must be satisfied along an optimal deforestation that ensures sustainability of an exhaustible resource with special reference to sub-Saharan African forest. This paper revealed that there is indeed divergence between the activities of profit maximizing charcoal producing firms in South Sahara Africa and the kind of maximization that will ensure social welfare. This is simply because environmental degradation and deforestation (externalities) associated with charcoal production are not internalized into the production function of the profit maximizing charcoal producing firms. These externalities would lead to unsustainability of the forest environment and subsequently deforestation. The externalities came about because of the differences in weight that is put on the noncommercial uses of the forest land by the individual farmer on one hand and, society on the other hand. Consequently, the optimal path of deforestation taken by the charcoal firms' yields outcome that is socially suboptimal. To deal with these, public policy interventions such as the use of Pigouvian tax and subsidies, public ownership, non-felling, regulation and internationally concerted action were recommended.

\section{References}

Adamm, F. W., Brew-Hammond, A., \& Essandoh, E. O. (2013). Relationships between energy use and income level for households in Ghana. European Scientific Journal, 9(16), 233-245.

Arnold, J. E. M., Kohlin, G., \& Person, R. (2006). Woodfuels, livelihoods and policy interventions: changing perspectives. World Development, 34(3), 596-611. https://doi.org/10.1016/j.worlddev.2005.08.008

Arnold, M., \& Persson, R. (2003). Comment: Reassessing the fuel wood situation in developing countries. International Forestry Review, 5(4), 379-383. https://doi.org/10.1505/IFOR.5.4.379.22660

Baillis, R. (2005). Fuel from the Savana: The social and environmental implications of the charcoal trade in SubSaharan Africa. Brekeley, Califonia, US: University of Califonia, Berkeley.

Baillis, R., Dirgo, R., Ghilardi, A., \& Masera, O. (2015). The Carbon footprint of traditional wood fuel. Nature climate change, 5, 266-272. https://doi.org/10.1038/nclimate2491

Brew-Hammond, A., \& Kemausuor, F. (2009). Energy for all in Africa -to be or not to be? Current Opinion in 
Environmental Sustainability, 1(1), 83-88. https://doi.org/10.1016/j.cosust.2009.07.014

Brown, R. L. (2014). Terror group Al Shahab doesn't smuggle ivory for cash. It sells charcoal. Christian Science Monitor.

Chidumayo, E. N., \& Gumbo, D. J. (2013). The environmental impacts of charcoal production in tropical ecosystems of the world: a synthesis. Energy for Sustainable Development, 17(2), 86-94. https://doi.org/10.1016/j.esd.2012.07.004

Ehui, S. K., \& Hertel, T. W. (1989). Deforestation and Agricultural Productivity in Cote d'Ivoire. American Journal of Agricultural Economics, 71, 703-711. https://doi.org/10.2307/1242026

ESDA. (2005). National Charcoal Survey Summary Report: Exploring the Potential for a Sustainabl Charcoal Industry in Kenya. Nairobi, Kenya: Energy for Sustainable Development Africa (ESDA).

FAO. (2008). Global Forest Resources Assessment. FAO Forestry Paper 147, Rome.

FAO. (2010). Global Forest Resources Assessment Report. FAO Forestry Paper 163, Rome.

FAOSTAT. (2014). http://faostat3.fao.org/faostat-gateway/go/to/browse/F/FO/E

GEF. (2013). Africa will import - not export -wood. Chevy Chase, Maryland, USA: Global Environment Fund (GEF).

ICRAF. (2002). Wood fuel policy and legislation in Eastern and Southern Africa. Regional Workshop held at the World Agroforestry Centre, 4-6 March 2002. Nairobi, Kenya: International Centre for Research in Agroforestry (ICRAF).

IEA. (2010). World Energy Outlook.Paris. France: International Energy Agency (IEA).

Iiyama, M., Chenevoy, A., Otieno, E., Kinyanjui, T., Ndegwa, G., Vandenabeele, J., Njenga, M., \& Johnson, O. (2014). Achieving sustainable charcoal in Kenya: Harnessing the opportunities for cross-sectoral integration. Technical Brief Nairobi, Kenya: World Agroforestry Centre/Stockholm Environment Institute.

Iiyama, M., Neufeldt, H., Dobie, P., Njenga, M., Ndegwa, G., Jamnadass, R. (2014). The potential of agroforestry in the provision of sustainable wood fuel in sub-Saharan Africa. Current Opinion in Environmental Sustainability, 6, 138-47. https://doi.org/10.1016/j.cosust.2013.12.003

IUCN. (1997). Strategic framework for sustainable natural resources management in Somalia. Somali Natural Resources Management Programme, International Union of Conservation Nations (IUCN) East Africa Regional Office.

Kammen, D. M., \& Lew, D. J. (2005). Review of technologies for the production and use of charcoal. Renewable and Appropriate Energy Laboratory Report. Energy and Resources Group \& Goldman School of Public Policy, University of California, Berkeley, CA.

KFS. (2013). Analysis of the charcoal value chain in Kenya. A report commissioned by the Kenya Forest Service (KFS), coordinated by the National REDD + Coordinating Office (NRCO) and carried out by Camco Advisory Services (Kenya) Limited. Nairobi, Kenya.

Kissinger, G., Herold, M., \& De. Sy. V. (2012). Drivers of deforestation and forest degradation: A synthesis report for REDD+ policymakers. Vancouver: Lexeme Consulting.

Luoga, E. J., Witkowski, E. T. F., \& Balkwill, K. (2000). Economics of charcoal production in miombo woodlands of eastern Tanzania: some hidden costs associated with commercialization of the resources. Ecological Economics, 35, 243-257. https://doi.org/10.1016/S0921-8009(00)00196-8

Minten, B., Sander, K., \& Stifel, D. (2013). Forest management and economic rents: evidence from the charcoal trade in Madagascar. Energy for Sustainable Development, 17(2), 106-115. https://doi.org/10.1016/j.esd.2012.08.004

Mugo, F., \& Ong, C. (2006). Lesson's from Eastern Africa's unsustainable charcoal trade. ICRAF Working Paper No 20. Nairobi, Kenya: World Agroforestry Centre. https://doi.org/10.5716/WP06119.PDF

Mwampamba, T. H. (2007). Has the wood fuel crisis returned? Urban charcoal consumption in Tanzania and its implications to present and future forest availability. Energy Policy, 35, 4221-34. https://doi.org/10.1016/j.enpol.2007.02.010

Mwampamba, T. H., Ghilardi, A., Sander, K., \& Chaix, K. J. (2013). Dispelling common misconceptions to improve attitudes and policy outlook on charcoal in developing countries. Energy for Sustainable 
Development, 17(2), 75-85. https://doi.org/10.1016/j.esd.2013.01.001

Naughton Treves, L., Kammen, D. M., \& Chapman, C. (2007). Burning biodiversity: Woody biomass use by commercial and subsistence groups in western Uganda's forests. Biological Conservation, 134, 232-241. https://doi.org/10.1016/j.biocon.2006.08.020

Neufeldt, H., Iiyama, M., Dobie, P., Roy, Hagen, Njenga, M., Ndegwa, G, Mowo, J., Kisoyan P., \& Jamnadass, R. (2015). Opportunities and challenges of landscape approaches for sustainable charcoal production and use. In Minang P. A., van Noordwijk M., Freeman O. E., Mbow C., de Leeuw J., \& Catacutan D. (Eds.), Climatesmart landscapes: multifunctionality in practice. Nairobi, Kenya: World Agroforestry Centre.

Peter, C., \& Sander, K. (2009). Environmental crisis or sustainable development opportunity? Transforming the charcoal sector in Tanzania: a policy note. Washington DC: World Bank.

Tabut, J. R. S., Dhillion, S. S., \& Lye, K. A. (2003). Firewood use in Bulamogi County, Uganda: Species selection, harvesting and consumption patterns. Biomass and Bioenergy, 25(6), 581-596. https://doi.org/10.1016/S0961-9534(03)00052-7

UNDP. (2014). NAMA Study for a Sustainable Charcoal Value Chain in Ghana. United Nations Development Programme (UNDP).

UNEP. (2014). Illegal trade in wildlife: the environmental, social and economic consequences for sustainable development. United National Assembly of the United Nations Environment Programme. Nairobi, Kenya: United Nations Environment Programme (UNEP).

vanderPlas, R. (2008). Charcoal and taxation in Africa. Discussion Draft.

WorldBank. (2010). Enabling reforms: A stakeholder-based analysis of the political economy of Tanzania's charcoal sector and the poverty and social impacts of proposed reforms. Washington DC: World Bank.

WSP. (2001). Rebuilding Somalia: Issues and possibilities for Puntland. WSP Somali Program.

Zulu, L. C. (2010). The forbidden fuel: charcoal, urban wood fuel demand and supply dynamics, community forest management and wood fuel policy in Malawi. Energy Policy, 38, 371730. https://doi.org/10.1016/j.enpol.2010.02.050

Zulu, L. C., \& Richardson, R. B. (2013). Charcoal, livelihoods and poverty reduction: evidence from subSaharan Africa. Energy for Sustainable Development, 17(2), 127-13. https://doi.org/10.1016/j.esd.2012.07.007

\section{Copyrights}

Copyright for this article is retained by the author(s), with first publication rights granted to the journal.

This is an open-access article distributed under the terms and conditions of the Creative Commons Attribution license (http://creativecommons.org/licenses/by/4.0/). 